Article

\title{
New Opportunities in Monitoring Safety of Journalists through the UN's 2030 Sustainable Development Agenda
}

\author{
Guy Berger \\ Communication and Information Sector, UNESCO, 75352 Paris, France; E-Mail: g.berger@unesco.org
}

Submitted: 25 November 2019 | Accepted: 19 January 2020 | Published: 25 February 2020

\begin{abstract}
This article highlights the potential for increased and more standardised monitoring of a range of aspects of the safety of journalists. This is in the light of a specific indicator that has been agreed by the UN as part of the Sustainable Development Goals (SDGs). The indicator concerned treats the safety of journalists as a benchmark for tracking progress on SDG target 16.10, which specifies "public access to information and fundamental freedoms" (UN Department of Economic and Social Affairs, n.d.), as a development aspiration. Inclusion of this indicator in the SDGs provides a universally legitimated framework with strong catalytic potential. All this holds a promise of improved, more comparative, and increased research output, as compared to the previous situation. The results of new research stimulated by this development, particularly at country level, could have real impact on the safety of journalists.
\end{abstract}

\section{Keywords}

journalism; monitoring; safety of journalists; Sustainable Development Goals; UNESCO; United Nations

\section{Issue}

This article is part of the issue "Rethinking Safety of Journalists" edited by Kristin Skare Orgeret (Oslo Metropolitan University, Norway) and William Tayeebwa (University of Makerere, Uganda).

(C) 2020 by the author; licensee Cogitatio (Lisbon, Portugal). This article is licensed under a Creative Commons Attribution 4.0 International License (CC BY).

\section{Introduction}

To move beyond fragmentary understandings of safety of journalists, we need comprehensive information that covers the breadth of the issue, and which also allows for the in-depth analysis of causes, consequences, and correctives over time. Such information is indispensable for awareness-raising and capacity-building, as well as for devising and operating mechanisms to ensure the effective protection of journalists and prosecution of their attackers (Berger, 2017). However, what information is relevant to the 'safety of journalists'? The 2012 UN Plan of Action on the Safety of Journalists and the Issue of Impunity (UNESCO, 2012a) treats 'safety' as a wide-ranging concept, covering both offline and online dimensions (UNESCO, 2019a). The implementation strategy of the UN Plan elaborates safety as "a broad category that extends from preventive, protective and pre-emptive measures, through to combating impunity and promoting a social culture which cherishes freedom of expression and press freedom" (UNESCO, 2012b). In both documents, a gender-sensitive orientation is taken, in response to distinctive issues concerning the safety of women journalists who are subjected to double attacksnot just as journalists, but as women doing journalism.

If 'safety' covers a range of issues, then this raises the question of how these may be assessed at a more granular level, perhaps in the form of a generic typology. Relevant to this endeavour is how the advent of the UN Sustainable Development Goals (SDGs) opens the way to new opportunities for defining and researching the safety of journalists in current times. The SDGs reflect change to a certain concept of 'development' which had long been critiqued for having a blinkered focus on technology, infrastructure, and economics. As a result of extensive advocacy, including by UNESCO and the Global Forum for Media Development, the 193 UN Member States that agreed to the SDGs accepted a more holistic approach. Thus, as an integral part of 'development,' they included Goal 16 which is summarised as 
"peace, justice and strong institutions" (UN Department of Economic and Social Affairs [UNDESA], n.d.). The underlying assumption is that for development processes to be sustainable, relevant actors should recognise the interdependence of goals like poverty reduction on the one hand, and peace and justice on the other. For example, armed conflict runs counter to ending povertyhence the relevance of building peace as part of integrated package. Likewise, the absence of justice and effective institutions fuels tensions which in turn threaten peace. Significantly, the inclusion of the concerns of Goal 16 in the SDGs is not just an issue of theoretical conceptualisation of 'development'; it also has material impact on national development strategies, and on international financing for related activities-including even on the potential for funding of research into the safety of journalists.

The SDGs are elaborated in the form of more specific targets that underpin achievement of the goals. These include target 16.10 which envisages achieving "public access to information and fundamental freedoms, in accordance with national legislation and international agreements" (UNDESA, n.d.). The particular target is not only an end in itself-i.e., integral to what counts as meaningful 'development.' There are also synergies between effective public access to information and strengthened freedoms and targets such as 16.3 (access to justice), 16.5 (anti-corruption), and 16.6 (transparent and accountable institutions). Target 16.10 can further be a means to advancing with other SDGs such as on health, gender equality, and the environment, which depend in large part on information access-which in turn is linked to issues such as freedom of expression, press freedom, and safety of journalists.

Going further, the UN General Assembly (UNGA) has agreed a package of indicators for measuring progress in reaching the SDGs. This includes two particular indicators for 16.10. One indicator examines the changing state of legal guarantees for access to information and their implementation (see UNESCO, 2019a). The other indicator, numbered as indicator 16.10.1, includes the safety of journalists. It reads: "Number of verified cases of killing, kidnapping, enforced disappearance, arbitrary detention and torture of journalists, associated media personnel, trade unionists and human rights advocates in the previous 12 months" (UNDESA, n.d.). It is immediately apparent that the extent of all these cases can tell us something significant about 16.10 on access to information and fundamental freedoms (and indeed also about the wider state of justice and strong institutions as conditions for sustainable development). Especially relevant to this article is the specification of journalists and media personnel in the agreed wording.

Indicator 16.10 .1 is important because the putting into place of research into, and reporting on, the journalistic component of this benchmark can help to enrich the ecosystem for investigating issues around the safety of journalists. This research can make a practical differ- ence to journalists and society by strengthening norms about safety, and by enabling evidence-led and effective measures to prevent attacks and to punish perpetrators. Expressed colloquially, it is a 'big deal' to have the safety of journalists, and the monitoring thereof, recognised within the UN's current development agenda which will run until 2030. This gives journalists' safety a particular framing that is both significant conceptually and politically, thereby enabling new opportunities to cast light on its relevance as an issue to society, both by advocates and by news media (see Pukallus \& Harrison, 2015). It further offers new prospects to mobilise funding to research the topic and to set in place, in an informed manner, the institutional systems needed to ensure that journalists can work without fear.

Within the UN system, global reporting in terms of indicator 16.10.1 started in 2016, with UNESCO compiling information on one of the data points (i.e., killings of journalists and media workers). These data are sent on to the Office of the United Nations High Commissioner for Human Rights (OHCHR), which has the status of 'custodian agency' for reporting on target 16.10.1. UNESCO and International Labour Organization (ILO) are recognised as "contributing agencies" to the indicator monitoring (UN Statistics Division [UNSD], 2016a).

A continuing challenge, however, is for the indicator to be taken up at national level, and to serve as a framework to strengthen local data-collection and reporting efforts. At the same time, the UNGA, UNESCO, and the Human Rights Council (UNHRC) urge that, in relation to the SDG Agenda, each individual government take seriously the matter of monitoring of the range of crimes against journalists. Thus, the UNGA (2019) in its 2019 Resolution A/C.3/74/L.45/Rev.1 repeats its call (first made in 2017) for "regular monitoring and reporting of attacks against journalists" and for "collecting and analysing concrete quantitative and qualitative data on attacks or violence against journalists, that are disaggregated by, among other factors, sex" (see also UNESCO, 2017a; UNHRC, 2018). Some states, ranging from Sweden through to Colombia, have mechanisms in place to exactly perform such monitoring and reporting (see also International Media Support, 2017). Evidently, a mechanism for monitoring is not the same as a methodology, and vice versa, but both are essential if systematic, credible, and regular data is to be produced over time.

\section{Operationalisation of the Indicator}

The SDG 16.10.1 indicator comprises five gross attacks on human rights-killing, kidnapping, enforced disappearance, arbitrary detention, and torture. Assessing the extent of these crimes (also with a gender-lens) as visited upon journalists can help identify the extent to which a society enjoys "public access to information" (UNDESA, n.d.) and respect for human rights and freedoms. Framed within SDG 16, this indicator further points us towards assessment of the fulfillment of duty by the State in en- 
suring that fundamental freedoms are protected in accordance with justice, the rule of law, and strong institutions, or whether impunity prevails for those who perpetrate the designated violations. It enables us to engage with the argument by Harrison and Pukallus (2018) that "the 'Politics of Impunity' is a policy of governance whereby impunity is used as a political tool by the state and state-sponsored actors to achieve journalistic self-censorship."

Operationalising indicator 16.10 .1 involves defining its terms and justifying these definitions in terms of international human rights standards. The UN Human Rights body OHCHR operates a classification system for human rights violations which underpins its Universal Human Rights Index (OHCHR, n.d.). This resource has relevance for the analytical understanding of different kinds of attacks as visited on journalists, and therefore upon what data might be collected in researching the various dimensions of the subject. There is also further elaboration within the discourse of the SDGs, in what is termed the "metadata" about the indicator (UNSD, 2018a). A useful way to understand this metadata was signaled at a workshop on the indicator convened by UNESCO and OHCHR in Geneva in July 2017 (UNESCO, 2017d), namely a framing in terms of 'who did what to whom, where and when, and with what effect.'

As regards the 'who' committed the violation, the metadata state that this may be state actors or others acting under government authority or with its complicity, tolerance, or acquiescence (all of whom should refrain from all violations of rights). It may be non-state actors (where the state retains an obligation to protect individuals against such abuses of rights by such third parties). Therefore, the indicator can cover all violations perpetrated by an agent of the State, as well as by those where the State fails to adequately investigate, punish, or redress abuses committed by non-state attackers. The issue of who perpetrated the attack becomes key for understanding the threat matrix against journalists (and protection mechanisms), as well as for the issue of ending impunity along the chain of actors engineering such crimes.

As regards the 'whom,' within the elaboration of the term 'journalists' in the metadata the term is taken to cover everyone who observes, describes, documents, and analyses events, statements, policies, and any proposition that can affect society, with the purpose of systematizing such information and gathering of facts and analyses to inform. This designates generic journalistic functions and it includes community media workers and socalled 'citizen journalists' when non-specialists momentarily play that role.

"Associated media personnel" (UNSD, 2018a) is not elaborated in the metadata, but the reference logically includes others working in the value chain of journalism production and dissemination, such as broadcasters, publishers, administrative staff, fixers, translators, and distributors. It can be noted that this broad conceptual- isation of 'whom' aligns with the perspectives generally agreed by UNESCO Member States and also features, in varying forms, in several UN decisions. In the reminder of this article, 'journalists' is used to include 'associated media personnel.'

In terms of 'what' has been done to violate safety, the metadata include legal definitions of the aspects of killing, kidnapping, enforced disappearance, arbitrary detention, and torture. These key violations are also correlated with criminal codes used under the International Classification of Crime for Statistical Purposes (ICCS), developed by the UN (UN Office on Drugs and Crime [UNODC], 2015a).

It is relevant to unpack some of these definitions as they bear on research into the safety of journalists, as the categories are not as straightforward as might otherwise be assumed.

One example is the term "arbitrary detention" (UNSD, 2018a), which according to the metadata, refers to any arrest or detention not properly based on grounds established by law, nor conforming to legal procedures. Complementing this definition, one can also here point to UN definitions, where the phrase designates detention without due process and safeguards, as outlined in Article 9(1) of the International Covenant on Civil and Political Rights (ICCPR) and the definition of "arbitrary deprivation of liberty" (UNHRC, 2012) developed by the UN Working Group on Arbitrary Detention. Significantly, the UNGA (2013), in resolutions such as A/RES/68/163 and others, has condemned all attacks and violence against journalists and media workers, mentioning inter alia arbitrary detention. In addition, the UNHRC (2016) in Resolution A/HRC/RES/33/2 urges all states to release arbitrarily detained journalists. The Council of Europe (2016) uses the formulations of "arbitrary arrest, unlawful detention." It will be easily apparent that making the judgement call about specific cases can vary, and that the necessary evidence may not be readily available. This underpins UNESCO's approach to NGO data on this matter, and the organisation's qualification that while considering the matter as part of safety of journalists, it is hard to obtain sufficient data to establish which cases of incarceration may be for reasons other than legitimate journalism (see UNESCO, 2014; UNESCO, 2018b).

Killing is defined in the metadata as any extrajudicial execution or other unlawful killing, but again this is not simple to operationalise. The issue of intention is signalled by the indicator metadata which necessitates that the envisaged and confirmed cases are those where a killing was either motivated by the victim engaging in activities as a journalist, or which were met by a failure of due diligence on the part of the State similarly motivated by the victim or associate engaging in activities as a journalist. Intentionality is also present in the ICCS schema, where killings are disaggregated into different categories, one of which is elaborated as "intentional homicide related to political agendas, including killings by terrorist groups with a political agenda, political as- 
sassination, and targeted killing of journalists for political reasons" (UNODC, 2015b).

The complexities around establishing intention in relation to the victim's journalistic role help explain why there are diverse data available on killings (such as shown in a database compiled by Sarikakis, 2017, and likewise by Torsner, 2017). Such diversity in verified cases can relate in part to official statistics, including ICCS relevant data. Additionally, while police data count charges, suspects, victims, and incidents, court data may comprise cases, convictions, and sentences. Some NGOs limit cases to those where there is a link to journalism, as is the methodology of the Committee to Protect Journalists (CPJ) and Reporters Without Borders (RSF), although they differ in some cases. CPJ (n.d.) considers a case "confirmed" as work-related only when reasonably certain that a journalist was murdered in direct reprisal for his or her work; in combat or crossfire; or while carrying out a dangerous assignment. Cases involving unclear motives, but with a potential link to journalism, are classified as "unconfirmed" and CPJ continues to investigate. They do not include journalists who are killed in accidents such as car or plane crashes. RSF (2018) states:

We gather detailed information that allows us to affirm with certainty or a great deal of confidence that the death, detention, abduction, or disappearance of each journalist was a direct result of their journalistic work. In regard to the number of deaths, we distinguish as much as possible between journalists who were deliberately targeted and those who were killed while reporting in the field. We do not include a journalist in the round-up if we are still investigating their death, detention, abduction, or disappearance because we are not yet confident that it was linked to their work.

The tally of the International Federation of Journalists (2019) is based on aggregating "targeted, bomb attacks and cross fire killings" and it also notes "accidental deaths." As noted by Elliott, Elbahtimy, and Srinivasan (2012) and (Mosdell, 2016), the International News Safety Institute concern has included media ancillary staff (drivers, translators, and security personnel) and this group's report for 2019 includes 'citizen journalists' (International News Safety Institute, 2019). In contrast, CPJ has a much tighter focus, thereby producing lower totals than does the Institute.

It is evidently difficult in many cases to establishespecially in a short space of time-whether a given journalist's death for apparently unrelated reasons (e.g., apparent traffic accident, robbery, suicide) was actually motivated by the victim's journalistic activities. This is partly why UNESCO monitoring does not prejudge the issue. This position is on the basis that the organisation's mandate for monitoring is to ensure that journalists are not killed with impunity, and that the rule of law is upheld in regard to all cases. This means that UNESCO operates from a standpoint that all unnatural deaths of journalists should be the subject of an official probe in which there is the investigative and legal competence to attribute the cause of death. The figures of killed journalists as recorded each year by UNESCO can be complemented, where requested by a state, with official information based upon judicial process about whether a particular fatality is demonstrated to be without link to journalistic activity.

Recognising that there is thus a diversity of approaches to safety of journalists by different actors, triangulation across the different data sources requires attention to what criteria are used to identify diverse cases. Equally, where there are shared points between systems, it is possible for researchers to develop a composite picture drawing from the range of available information. At the same time, the SDG metadata, informed by the Universal Human Rights Index and ICCS frameworks, offers a typology of more standardized and generic categories, and it enjoys UN endorsement. This makes it an authoritative and central point that researchers can consider. It also has unique potential impact, and not only on killings of journalists but also on the raft of other kinds of attacks.

\section{Status of the Indicator and Scope for Elaboration}

The UN Statistical Commission has worked with UN agencies to develop a tier system for the global indicators. As part of this process, indicator 16.10 .1 was initially categorized as a Tier III indicator (UNSD, 2016a), meaning that it was originally viewed as either having no established methodology and standards, or, that its methodology and standards were still being developed and/or tested (UNSD, 2016b). OHCHR initiated efforts to upgrade the tier rating for this indicator, working with UNESCO and ILO (UNSD, 2016c), and this partnership succeeded to secure reclassification as a Tier II indicator in November 2017 (UNSD, 2018b). Accordingly, 16.10.1 is now classified at the level of indicators which have conceptually clear, established methodology and standards available but data are not regularly produced by countries. This revised status could enhance prospects for national level uptake of this indicator as part of country-level monitoring and reporting on SDG 16.10, which would then begin to elevate the indicator for Tier I. The status of top tier (Tier I) of SDG indicators requires that data are regularly produced for at least 50 percent of countries and of the population in every region where the indicator is relevant. This might be possible in at least a number of interested countries.

Within this focus of securing data at country-level, there are also a number of areas where research in relation to 16.10 .1 can be further elaborated, and even in places where the five most gross attacks on the human rights of journalists are not experienced, but where other kinds of crimes against them are committed and go unpunished. 
Impunity for attacks on journalists is not explicitly listed in indicator 16.10.1. But it is logically linked, for example, in the dramatically high number of fatal attacks that go unpunished (nine out of ten; see UNESCO, 2019b) which is widely regarded as a factor in feeding further killings. Hence, mapping trends in reductions or increases in attacks also needs to take account of the situation concerning trends in impunity for these attacks. This provides a more comprehensive and medium-term perspective for making progress on safety of journalists, and it highlights linkages between "public access to information and fundamental freedoms" (SDG 16.10) and other parts of Goal 16 such as target 16.3 which specifically seeks to "promote the rule of law at the national and international levels and ensure equal access to justice for all" (UNDESA, n.d.). For these reasons, UNESCO's contribution of data for global monitoring of 16.10 .1 for the UN includes impunity figures.

There are also several types of attacks not explicitly referred to in the terms of indicator 16.10.1's list of five gross violations and abuses of human rights (killing, torture, etc.). Attacks such as harassment, intimidation, assault, and cyber-attacks are evidently very serious in terms of journalists exercising their freedom of expression and facilitating public access to information. These kinds of attacks can therefore certainly be considered to be relevant to monitoring 16.10 and how the indicator is interpreted. Indeed, UN resolutions increasingly draw attention to the panoply of attacks and violence. For example, in its 2019 Resolution A/C.3/74/L.45/Rev.1, the UNGA (2019) stated it was:

Deeply concerned by all human rights violations and abuses committed in relation to the safety of journalists and media workers, including killing, torture, enforced disappearance, arbitrary arrest and arbitrary detention, expulsion, intimidation, harassment, online and offline threats and other forms of violence.

The resolution further:

Condemns unequivocally all attacks and violence against journalists and media workers, such as torture, extrajudicial killings, enforced disappearances, arbitrary arrest and arbitrary detention, expulsion, intimidation, threats and online and offline harassment, including through attacks on, or the forced closure of, their offices and media outlets. (UNGA, 2019)

The resolution further expresses alarm "at instances in which political leaders, public officials and/or authorities denigrate, intimidate or threaten the media, including individual journalists, which increases the risk of threats and violence against journalists" (UNGA, 2019).

Also significant is a clause which also condemns the specific attacks on women journalists and media workers in relation to their work, such as gender-based discrimination and violence, including online and offline sex- ual harassment, intimidation and incitement to hatred against women journalists (UNGA, 2019).

It may be further noted that a spectrum of types of attacks has been recognised in other UN positions which also go beyond the five explicitly listed in the wording of the indicator. For example, the Human Rights Committee General Comment 34 on Article 19 of the ICCPR states that "the harassment, intimidation or stigmatization of a person, including arrest, detention, trial or imprisonment for reasons of the opinions they may hold, constitutes a violation of article 19, paragraph 1" (UNHRC, 2011). As regards the ICCPR Article 19.3, General Comment 34 affirms that under no circumstances "can an attack on a person, because of the exercise of his or her freedom of opinion or expression, including such forms of attack as arbitrary arrest, torture, threats to life and killing, be compatible with article 19" (UNHRC, 2011).

A case can be made that all these issues could be addressed through the phrase "other harmful acts" (UNSD, 2018a), which although not among the five categories cited explicitly in the indicator, is elaborated in the metadata. There, the phrase is explained as referring to acts by direct or indirect agents of the State which cause harm or intend to cause harm, and which are motivated by the victim engaging in activities as a journalist (or trade unionist or human rights defender). Harm covers, according to the metadata, acts correlating to various ICCS codes such as sexual violence, threat, coercion, and acts intended to induce fear or emotional distress, including harassment. It further adds acts that trespass against the person, including invasion of privacy (UNSD, 2018a). Relevant here is that recent UN resolutions, including that in $2019 \mathrm{~A} / \mathrm{C} .3 / 74 / \mathrm{L} .45 /$ Rev.1, identify unlawful or arbitrary surveillance or interception of communications as a risk to their safety (UNGA, 2019). In other resolutions, the UN has regularly condemned surveillance as having a chilling effect on freedom of expression, and UNESCO and UNHRC have noted the adverse impact on confidentiality of journalistic sources in particular. Surveillance as part of "other harmful acts" (UNSD, 2018a) could intersect with ICCS Code 0211 (referring, inter alia, to the invasion of privacy).

Not explicitly referred to in the metadata document, but potentially also relevant to "other harmful acts" (UNSD, 2016b) are ICCS codes for cases of bullying in the workplace (020811), bullying outside the workplace (020819), cyber-bullying (0208), and cyber-stalking (02082).

Attacks such as forcing a journalist into exile (tracked to an extent by (PJ), and seizure/confiscation of kit, are not as easily correlated with the ICCS framework, but connections could be possibly drawn so that actorsespecially at national level-might decide to optionally include such additions (where relevant) to the interpretation of "other harmful acts" (UNSD, 2016b).

Amongst the ICCS codes, the issue of 'threats,' which could be interpreted as expressions of intent to cause 
harm (as per the metadata) would appear to call out for particular attention. Tracking the issue could help establish, for instance, the extent of correlations between death threats and actual journalists killed. The experience of Italian NGO Ossigeno (n.d.) has shown some way forward in collecting and verifying data on threats. The results can give more impetus at country level to protection mechanisms, as well as help to strengthen advocacy to end impunity for threats that serve to intimidate and obstruct journalists in their work to make information public.

In overview, the metadata for 16.10 .1 affords within the SDG monitoring framework, attention to a range of attacks in addition to the five categories cited in the wording of the indicator. This is recognized in a resolution at the UNHRC in 2018 (Resolution A/HRC/39/L.7) that calls upon:

States to strengthen national data collection, analysis and reporting on the number of verified cases of killing, kidnapping, enforced disappearance, arbitrary detention, torture and other harmful acts against journalists and associated media personnel, in accordance with Sustainable Development Goal indicator 16.10.1. (UNHRC, 2018)

In its 2019 Resolution on safety of journalists A/C.3/74/L.45/Rev.1, the UNGA (2019) has echoed this wording. It is in this light that one can take note of a 2019 study by civil society groups that serves as a 'shadow report' to official SDG monitoring processes, in regard to eight Latin American countries (Voces del Sur, 2019). This work expands beyond killings and the other human rights violations cited in the indicator, and also gives attention to "aggression and attacks," "stigmatizing discourse," "access to information," "judicial procedures against media outlets and journalists," "abuse of state power," "juridical framework contrary to standards," and "internet restrictions" (Voces del Sur, 2019); the study further assesses gendered dimensions where relevant. Such initiatives illustrate how the agenda of the SDGs enables comprehensive and action-oriented research into the safety of journalists, keeping in mind as well the value of a gendered analysis. In countries where journalists are not subjected to the most gross violations or abuses of human rights, the "other harmful acts" (UNSD, 2018a) still call out for monitoring. In this sense, the SDG 16.10.1 opportunity has universal utility.

It is further worth observing that there appears to be potential for research using indicator 16.10.1 and "other harmful acts" (UNSD, 2018a) to link up with crime statistics at national levels. This would entail data arising from institutional practice of official agencies that use the ICCS systems and which might be persuaded-in the interests of SDG reporting - to disaggregate when victims are journalists or associated media personnel (or trades unionists and human rights defenders).

\section{UNESCO'S Monitoring of Safety in Relation to Operationalising Indicator $\mathbf{1 6 . 1 0 . 1}$}

UNESCO's mandate for monitoring journalism safety, limited to the data points of killings and impunity, predates SDG indicator 16.10.1. However, it provides a basis that in terms of which the organisation now also feeds information into SDG monitoring at global level. The tracking by UNESCO also contributes to the Universal Periodic Review process at the UNHRC as well to the governing bodies at UNESCO itself.

The mandate stems originally from Resolution 29 'Condemnation of violence against journalists,' adopted at the 29th General Conference in 1997, which invited the Director-General to "condemn assassination and any physical violence against journalists as a crime against society" (UNESCO, 1997). This finds continuing partial expression in regular media statements by the DirectorGeneral about killings as they happen, and it enables UNESCO to produce annual comparative totals. These are accompanied by ongoing mandates from the intergovernmental council of the organisation's International Programme for the Development of Communication (IPDC), to include information on judicial follow-up to the killings of journalists (see UNESCO, 2018a).

Torsner (2017, p. 133) observes that UNESCO's monitoring of killing and impunity "is useful for advocacy about the need for the state to fulfil its duty in providing protection and prosecuting the perpetrators of fatal attacks on journalists," but signals further that "this alone has its limitations if the goal is to try to understand the nature, dynamics and consequences of threats (some of which culminate in killings) and to describe shifting trends in journalism safety."

The constraint in UNESCO's role appears to be less of a political issue than a practical one. As regards the 1997 mandate, to date the issue of "any physical violence" (UNESCO, 1997) has not been systematically monitored at global level, nor uniformly condemned or otherwise reported upon. It would appear in principle, that this wording in the organisation's mandate could at least include "torture" as well as "kidnapping" and "enforced disappearance" (UNSD, 2018a). It could also include "assault" or "attempted murder" (UNSD, 2018a) which are variables that can be correlated with ICCS codes mentioned in the SDG metadata.

What "any physical violence" (UNESCO, 1997) does not cover is the category of non-physical attacks on journalists-such as through intimidation (online or offline) or digital disruptions and intrusions (such as DDOS attacks or unwarranted surveillance, content interference, or disproportionate blocks/filters). However, also significant is Resolution 53 of UNESCO's 36th General Conference in 2011 which provides for the Secretariat to:

Monitor, in close cooperation with other United Nations bodies and other relevant organizations active in this field, the status of press freedom and safety 
of journalists, with emphasis on cases of impunity for violence against journalists including monitoring the judicial follow-up through the Intergovernmental Council of the IPDC and to report on the developments in these fields to the biannual General Conference. (UNESCO, 2011)

The wording of this 2011 mandate includes "the state of press freedom" (UNESCO, 2011), which increasingly is affected by issues such as digital attacks, harassment and intimidation, and arbitrary detention, which are not directly covered by the two earlier mandates mentioned above.

At the same time, the immensity of monitoring all these issues at global level, while both possible in terms of the UNESCO Member States' mandates to the secretariat, as well as the SDG metadata, is beyond the practical capacity of the organisation. Relevant to mention, however, are country-level research instruments. One of these is comprised by UNESCO's country-based Media Development Indicators (MDIs) assessments which have been done in more than 20 countries in the past ten years (UNESCO, n.d.). These studies use a research standard endorsed by UNESCO's IPDC. The relevant section here is mainly under key indicator 3.13 "journalists, associated media personnel and media organisations can practice their profession in safety," covering "threats, harassment, surveillance, physical attacks, unlawful detentions" (UNESCO, n.d.). The "threats, harassment and surveillance" (UNESCO, n.d.) categories do lend themselves to particular national level assessments, although methodologies for assessing these raise questions. It may be noted, however, that the Council of Europe's platform for accredited NGOs to report problems like "threats" (Council of Europe, 2020), etc., does give a selfreported measure. By its nature, however, covert surveillance of journalists in particular is hard to monitor.

In selected countries, national monitoring of the safety of journalists can also be synergized with the specialized UNESCO/IPDC Journalists' Safety Indicators (UNESCO, 2015b). The Journalists' Safety Indicators studies assess the state of journalists' safety and the issue of impunity by discussing safety across many axes. These include surveillance or trailing, harassing phone calls, arbitrary judicial or administrative harassment, aggressive declarations by public officials, or other forms of pressure that can jeopardise the safety of journalists in pursuing their work. In addition, these indicators assess the actions of various stakeholders in promoting a safer environment for media workers.

Thus, both the MDIs and the Journalists' Safety Indicators offer opportunities at national level to feed into country-based monitoring and reporting systems on SDG 16.10.1. This mitigates that UNESCO does not systematically have a granular monitoring at global scale of the other forms of attack beyond killings as listed in indicator 16.10.1 and "other harmful acts" (UNSD, 2018a). These existing approved research instruments, and the wider mandates, can be useful for actors in individual countries linking up to the SDGs opportunity.

\section{Putting Focus on Elaborated Monitoring at the National Level}

A meeting of experts concerning indicator 16.10 .1 at UNESCO in May 2018 was premised on the idea of assessing the potential for actors involved in monitoring safety to align and expand their work on the range of attacks as per the metadata. At the same time, the concept note for the occasion also took cognizance of a counter argument that rather than spreading resources on monitoring and reporting on additional attacks, priority instead be given to ramping up co-operation around killings and impunity. At the same time, the note further observed that under SDG's monitoring scenario, countries also have the opportunity to elaborate their own indicators. Also reflected in the note was the question of whether global work could contribute at national level, to building domestic capacity (possibly on a multi-stakeholder model) in the form of sustainable local mechanisms for monitoring attacks and impunity (e.g., based in national statistics commissions, human rights commissions, justice ministries, or other bodies).

Encouragement for action at the country level was a major outcome of a global consultation on the UN Plan of Action on the Safety of Journalists and the Issue of Impunity in 2017 (UNESCO, 2017b, 2017c). It is also evident in a decision taken at UNESCO's 206th Executive Board in April 2019, which encouraged Member States to develop national information, prevention, protection, and prosecution systems, "as well as reporting on Sustainable Development Goal (SDG) indicator 16.10.1 including, where relevant, at the upcoming review during the High-Level Political Forum in July 2019" (UNESCO, 2019d). Also relevant is a decision by the IPDC in November 2018 which called for "enhancing current monitoring in collaboration with UNESCO's Institute of Statistics (UIS) as appropriate, in order to align and reinforce synergies with the methodology of the Universal Periodic Review (UPR) [of the UNHRC] and the overall reporting on SDG 16.10.1" (IPDC, 2018). Such enhancement and its synergies with the UIS may hold potential for strengthening national level initiatives.

UNESCO is not directly involved in national level SDG monitoring or reporting, which is a voluntary issue for each Member State. Each year, a number of states volunteer to report to the UNGA about progress in a mechanism called the 'Voluntary National Review.' In addition, a number of countries operate mechanisms for ongoing assessment for their domestic purposes, such as reporting to parliament or the government.

Of significance to this monitoring is a suggestion made at the 2018 expert meeting at UNESCO. This was that UNESCO should supplement its Journalism Safety Indicators with a model data collection template to offer to actors at national level. Following this, UNESCO has de- 
veloped a voluntary guideline as a contribution to the UN Development Programme's technical assistance to states in SDG monitoring (see UN Development Programme, 2019). This guideline indicates explicitly that the offered options may also be of value to civil society and media actors seeking to work with governmental SDG-monitoring processes, and/or wishing to produce shadow reports. The options cover data points for assessing the safety of journalists through examining relevant laws, policies, personnel, and the existence of a monitoring system on the subject. Further, as regards the range of attacks, the data points include "killings," "credible threats," and "intimidation," as well as indicator 16.10.1's reference to "enforced disappearance, kidnapping, arbitrary detention and torture" (UNSD, 2018a) with the corresponding ICCS categories.

\section{Way Forward}

A focus on national level possibilities informs the guide by the International Freedom of Expression Exchange (2019) which notes:

The UN Agenda 2030 calls on States to establish their own concrete national and sub-national indicators for tracking improvements, as well as to establish national review and accountability mechanisms. Civil society can play a crucial role in monitoring and advocating for progress. For example, in some countries, implementation plans are developed with civil society; in others, civil society prepares alternative monitoring reports.

As regards academia in particular, under the frame of the UN Plan of Action on the Safety of Journalists and the Issue of Impunity, UNESCO in 2015 initiated a Research Agenda for Academics with a list of ten suggested research topics on safety issues (Berger, 2018; UNESCO, 2015a). This pre-dated the adoption of the SDGs, however it remains relevant to research linked to indicator 16.10.1. A number of publications have emerged directly or indirectly in response to the Agenda and to safety of journalists within the SDGs (see Baker, Murrell, \& Martin, 2018, who published a special edition of the Australian Journalism Review; Brambila \& Hughes, 2019; Carlsson \& Pöyhtäri, 2017; and Fadnes, Skare Orgeret, \& Krøvel, 2019, with a special edition of the journal Conflict and Communication Online). According to the latter, at least 14 articles relevant to the UNESCO Research Agenda were published in Journalism, Journalism Practice, Data Journalism, and Journalism Studies in 2016, 2017, and 2018. There is certainly scope at country level to use the Agenda to further operationalise the wider remit of "other harmful acts" (UNSD, 2016b) against journalists.

In addition, case studies could document non-fatal attacks, such as threats of death and other physical harms to journalists and their families in a given society-and then assess if such data serves as a reliable predictor of a threshold for when violent acts actually get committed (see also Torsner, 2017; UNESCO, 2019c). Researching the local impact on the psychological health of reporters is also important (see Jukes, 2015). Subnational research is a further area that produces valuable insights (see Brambila, 2017). In 2012, Elliott et al. remarked that local journalists constituted over 80 percent of journalist deaths during the previous decade (see also UNESCO, 2019b), which again draws attention to understanding national and subnational contexts, and indeed to whether there are any relationships within each of these environments between the extent of fatal and non-fatal attacks occurring there.

Case studies might also feed into other national opportunities for SDG monitoring and reporting. The data could also enrich research events on the safety of journalists such as those to date which have accompanied UNESCO's global World Press Freedom Day conference in Helsinki (in 2016), Jakarta (in 2017), Accra (in 2018), and Addis Ababa (in 2019), and events around the International Day to End Impunity for Crimes Against Journalists (IDEI) which is commemorated each 2 November. There is also the opportunity of the annual conference organised by Oslo Metropolitan University, which is timed around IDEI. Presented by the University's research group called 'Media, War and Conflict,' the event marked its fifth edition in 2019 (MEKK, 2019). The 2018 gathering addressed the 'with what effect' aspect of 'who did what to whom,' by investigating links between attacks on journalists and the practice of selfcensorship (see Berger, 2018b).

In addition, the Centre for the Freedom of the Media at Sheffield University (n.d.) has created a Facebookbased journalism safety research network, and along with others has organised special panels at annual conferences of the International Association for Media and Communication Research. Additional data relevant to 16.10.1 may emerge from the Worlds of Journalism (n.d.) study consortium, which previously surveyed 27,500 journalists in 67 countries, and which has now decided to include safety-related questions in their next round of global research.

In summary, there is much momentum and there is also much potential for research at national level to become part of making history in harnessing efforts to the opportunity of SDG 16.10.1. This can also help develop standard categories and data sources that can facilitate comparisons from year to year and improve potential for aggregation of data across countries. The outputs can help ensure the knowledge needed for achieving safety of journalists. In turn, this can help inform change so as to progress public access to information and fundamental freedoms, as well as to power momentum in each concerned country towards achieving peace, justice, and strong institutions, and the synergies between these objectives and the rest of the SDG agenda. 


\section{Acknowledgments}

This article is based on a paper presented at the conference of the International Association for Media and Communications Research, Madrid, 7-11 July, 2019. The ideas have been sharpened through discussion with Prof Jackie Harrison, Diana Maynard, and Sara Torsner of the Centre for Freedom of the Media, at the University of Sheffield, UK. This contribution was written as part of the author's work as Director for Freedom of Expression and Media Development, UNESCO. However, the ideas and opinions expressed are not necessarily those of UNESCO and do not commit the organisation.

\section{Conflict of Interests}

The author declares no conflict of interests.

\section{References}

Baker, A. J., Murrell, C., \& Martin, F. (2018). A note from the guest editors (safety of journalists). Australian Journalism Review, 42(1), 5-8.

Berger, G. (2017). Mapping attacks on the media. Paper presented at the conference "Impunity of murders of journalists: A challenge to freedom of the media," Vienna, Austria. Retrieved from https://www.osce.org/ fom $/ 366041$ ?download=true

Berger, G. (2018). UNESCO's safety of journalists agenda: What impact? Australian Journalism Review, 40(2), 29-35. Retrieved from https://search.informit. com.au/documentSummary; $d n=222222520041880$; res=IELAPA

Brambila, J. A. (2017). Forced silence: Determinants of journalist killings in Mexico's states, 2010-2015. Journal of Information Policy, 7, 297-326. https://doi. org/10.5325/jinfopoli.7.2017.0297

Brambila, J. A., \& Hughes, S. (2019). Violence against journalists. In T. P. Vos \& F. Hanusch (Eds.), The international encyclopedia of journalism studies (pp. 1614-1621). Boston, MA: Wiley-Blackwell. https:// doi.org/10.1002/9781118841570.iejs0248

Carlsson, U., \& Pöyhtäri, R. (Eds.). (2017). The assault on journalism: Building knowledge to protect freedom of expression. Gothenburg: Nordicom.

Centre for the Freedom of the Media at Sheffield University. (n.d.). Homepage. Centre for the Freedom of the Media. Retrieved from www.cfom.org.uk

Committee to Protect Journalists. (n.d.). Methodology. Committee to Protect Journalists. Retrieved from https://cpj.org/data/methodology

Council of Europe. (2016). Recommendation CM/Rec(2016)4[1] of the Committee of Ministers to member States on the protection of journalism and safety of journalists and other media actors. Council of Europe. Retrieved from https://search. coe.int/cm/Pages/result_details.aspx?Objectld= 09000016806415d9\#_ftn1
Council of Europe. (2020). Platform to promote the protection of journalism and safety of journalists. Council of Europe. Retrieved from https://www.coe.int/ en/web/media-freedom/home

Elliott, S., Elbahtimy, M., \& Srinivasan, S. (2012). Safety of journalists (CGHR Working Paper No. 4). Cambridge: University of Cambridge Centre of Governance and Human Rights. Retrieved from https:// www.repository.cam.ac.uk/bitstream/handle/ 1810/245114/CGHR_WP_4_2012_JournalistsReport.pdf?sequence $=4$ \&isAllowed $=y$

Fadnes, I., Skare Orgeret, K., \& Krøvel, R. (2019). Where are we now? (Almost) a decade with the UN plan of action on the safety of journalists and the issue of impunity. Conflict and Communication Online, 18(1), 1-6. Retrieved from http://www.cco.regener-online. de/2019_1/pdf/introduction2019.pdf

Harrison, J., \& Pukallus, S. (2018). The politics of impunity: A study of journalists' experiential accounts of impunity in Bulgaria, Democratic Republic of Congo, India, Mexico and Pakistan. Journalism. Retrieved from https://journals.sagepub.com/doi/pdf/ $10.1177 / 1464884918778248$

International Federation of Journalists. (2019). In the shadow of violence: Journalists and media staff killed in 2018. Brussels: International Federation of Journalists. Retrieved from https://www.ifj.org/ fileadmin/user_upload/IFJ_2018_Killed_Report_ FINAL_pages.pdf

International Freedom of Expression Exchange. (2019). Sustainable Development Goals (SDGs): What role for freedom of expression? IFEX. Retrieved from https://ifex.org/sustainable-development-goalssdgs-what-role-for-freedom-of-expression

International Media Support. (2017). Defending journalism: How national mechanisms can protect journalists and address the issue of impunity. A comparative analysis of practices in seven countries. Copenhagen: International Media Support. Retrieved from https://www.mediasupport.org/wp-content/ uploads/2017/10/1_Journalist-Protection-BookDigital-1.pdf

International News Safety Institute. (2019). Killing the messenger. London: International News Safety Institute.

International Programme for the Development of Communication. (2018). Decisions taken by the 31st council session of the International Programme for the Development of Communication (IPDC), 21-22 November 2018. Paris: UNESCO. Retrieved from https:// unesdoc.unesco.org/ark:/48223/pf0000266235

Jukes, S. (2015). Journalists at risk: Looking beyond just physical safety. Paper presented at $5^{\text {th }}$ biennial conference "The Future of Journalism," Cardiff, UK. Retrieved from eprints.bournemouth.ac.uk/ 23308/1/Jukes\%20-\%20Future\%20of\%20Journalism \%20paper.pdf

MEKK. (2019). Safety of journalists: Digital safety, 2019. 
Media, War and Conflict (MEKK). Retrieved from https://blogg.hioa.no/mekk/conferences/safety-ofjournalists-digital-safety-2019

Mosdell, N. (2016) Mapping the parameters of peril. In S. Cottle, R. Sambrook, \& N. Mosdell (Eds.), Reporting dangerously: Journalist killings, intimidation and security (pp. 36-58). London: Palgrave Macmillan.

Office of the High Commissioner on Human Rights. (n.d.). Welcome to UHRI. Office of the United Nations High Commissioner for Human Rights. Retrieved from https://uhri.ohchr.org/en

Ossigeno. (n.d.). Homepage. Ossigeno. Retrieved from https://www.ossigeno.info

Pukallus, S., \& Harrison, J. (2015). Journalists die: Who cares? British Journalism Review, 26(1), 63-68.

Reporters Without Borders. (2018). Worldwide round up of journalists killed, detained, held hostage or missing in 2018. Paris: Reporters Without Borders. Retrieved from https://rsf.org/sites/default/files/worldwilde_ round-up.pdf

Sarakakis, K. (2017). Killings of journalists worldwide: The full costs of a free press. Vienna: Media Governance and Industries Research Lab, University of Vienna. Retrieved from http://mediagovernance.univie.ac.at/ research/democracy-under-pressure/killings-ofjournalists-worldwide

Torsner, S. (2017). Measuring journalism safety: Methodological challenges. In U. Carlsson \& R. Pöyhtäri (Eds.), The assault on journalism: Building knowledge to protect freedom of expression (pp. 131-140). Gothenburg: Nordicom.

UNESCO. (1997). Resolution 29 "Condemnation of violence against journalists". Paris: UNESCO. Retrieved from http://www.unesco.org/new/fileadmin/ MULTIMEDIA/FIELD/Brussels/pdf/ipdc_resolution_ 29.pdf

UNESCO. (2011). Records of the general conference, 36th session. Paris, 25 October -10 November 2011, v. 1: Resolutions. Paris: UNESCO. Retrieved from https:// unesdoc.unesco.org/ark:/48223/pf0000215084

UNESCO. (2012a). UN plan of action on the safety of journalists and the issue of impunity. Paris: UNESCO. Retrieved from https://en.unesco.org/un-plan-actionsafety-journalists

UNESCO. (2012b). Implementation strategy 2013-2014: UN plan of action on the safety of journalists and the issue of impunity. Paris: UNESCO. Retrieved from http://www.unesco.org/new/fileadmin/ MULTIMEDIA/HQ/Cl/Cl/pdf/official_documents/ Implementation_Strategy_2013-2014_01.pdf

UNESCO. (2014). World trends in freedom of expression and media development. Paris: UNESCO. Retrieved from http://unesdoc.unesco.org/images/0022/ 002270/227025e.pdf

UNESCO. (2015a). Towards a research agenda on the safety of journalists. Paris: UNESCO. Retrieved from http://www.unesco.org/new/fileadmin/ MULTIMEDIA/HQ/Cl/Cl/images/Themes/Freedom_
of_expression/safety_of_journalists/Draft_Research_ Agenda_Safety_of_Journalists_06_2015.pdf

UNESCO. (2015b). Journalists' safety indicators: National level. Based on UNESCO's Media Development Indicators. Paris: UNESCO. Retrieved from https://unesdoc. unesco.org/ark:/48223/pf0000260893

UNESCO. (2017a). Records of the general conference (39 C/Resolutions). Paris: UNESCO. Retrieved from http://unesdoc.unesco.org/images/0026/002608/ 260889e.pdf

UNESCO. (2017b). Multi-stakeholder consultation on strengthening of the UN plan of action on the safety of journalists and the issue of impunity. Paris: UNESCO. Retrieved from https://en.unesco.org/ sites/default/files/report_-_multi-stakeholder_ consultation.pdf

UNESCO. (2017c). Strengthening of the UN plan of action on the safety of journalists and the issue of impunity. Paris: UNESCO. Retrieved from https://en.unesco.org/sites/default/files/options_ geneva_consultation.pdf

UNESCO. (2017d). UNESCO convenes technical workshop on measuring the safety of journalists. UNESCO. Retrieved from https://en.unesco.org/news/unescoconvenes-technical-workshop-measuring-safetyjournalists

UNESCO. (2018a). 2018 DG report on the safety of journalists and the danger of impunity (Cl-18/COUNCIL31/6 REV.2). Paris: UNESCO. Retrieved from http://unesdoc.unesco.org/images/0026/002658/ 265828e.pdf

UNESCO. (2018b). World trends in freedom of expression and media development. Paris: UNESCO. Retrieved from https://en.unesco.org/world-mediatrends-2017

UNESCO. (2019a). Access to information: A new promise for sustainable development. Paris: UNESCO. Retrieved from https://unesdoc.unesco.org/ark:/ 48223/pf0000371485

UNESCO. (2019b). Intensified attacks, new defences: Developments in the fight to protect journalists and end impunity. Paris: UNESCO. Retrieved from https:// unesdoc.unesco.org/ark:/48223/pf0000371487

UNESCO. (2019c). Academics strengthen research into safety of journalists. UNESCO. Retrieved from https://en.unesco.org/news/academics-strengthenresearch-safety-journalists

UNESCO. (2019d). Decisions adopted by the executive board at its 206th session. Paris: UNESCO. Retrieved from https://unesdoc.unesco.org/ark:/48223/ pf0000367821/PDF/367821eng.pdf.multi

UNESCO. (n.d.). Media development indicators (MDIs). UNESCO. Retrieved from https://en.unesco.org/ programme/ipdc/initiatives/mdis

United Nations Department of Economic and Social Affairs. (n.d.). Sustainable development goal 16. Sustainable Development Knowledge Platform. Retrieved from https://sustainabledevelopment.un. 
org/sdg16

United Nations Development Programme. (2019). Guidance for reporting on SDG 16. Oslo: Oslo Governance Centre. Retrieved from https://www. sdg16hub.org/system/files/2019-05/SDG\%2016\%20 Reporting\%20Guidance\%20Final.pdf

United Nations General Assembly. (2013). The safety of journalists and the issue of impunity (A/RES/68/163). New York, NY: United Nations General Assembly. Retrieved from https://undocs.org/A/RES/68/163

United Nations General Assembly. (2019). The safety of journalists and the issue of impunity. New York, NY: United Nations General Assembly. Retrieved from https://undocs.org/A/C.3/74/L.45/Rev.1

United Nations Human Rights Council. (2011). General comment no. 34 (CCPR/C/GC/34). Geneva: United Nations Human Rights Council. Retrieved from https://www2.ohchr.org/english/bodies/hrc/docs/ gc34.pdf

United Nations Human Rights Council. (2012). Report of the working group on arbitrary detention (A/HRC/22/44). Geneva: United Nations Human Rights Council. Retrieved from https://undocs.org/ en/A/HRC/22/44

United Nations Human Rights Council. (2016). The safety of journalists (A/HRC/RES/33/2). Geneva: United Nations Human Rights Council. Retrieved from https:// undocs.org/A/HRC/RES/33/2

United Nations Human Rights Council. (2018). The safety of journalists. Geneva: United Nations Human Rights Council. Retrieved from https://undocs.org/A/HRC/ $\mathrm{RES} / 39 / 6$

United Nations Office on Drugs and Crime. (2015a). International classification of crime for statistical purposes. United Nations Office on Drugs and Crime. Retrieved from http://www.unodc.org/unodc/en/dataand-analysis/statistics/iccs.html

United Nations Office on Drugs and Crime. (2015b). International classification of crime for statistical purposes. Vienna: United Nations Office on Drugs and Crime. Retrieved from http://www.unodc.org/ documents/data-and-analysis/statistics/crime/ ICCS/ICCS_English_2016_web.pdf

United Nations Statistics Division. (2016a). Provisional proposed tiers for global SDG indicators. New York, NY: United Nations Statistics Division. Retrieved from http://unstats.un.org/sdgs/files/meetings/ iaeg-sdgs-meeting-03/Provisional-Proposed-Tiersfor-SDG-Indicators-24-03-16.pdf

United Nations Statistics Division. (2016b). Update on the work of the IAEG-SDGS: Informal briefing on the global indicator framework for the SDGs. New York, NY: United Nations Statistics Division. Retrieved from https://unstats.un.org/sdgs/files/ga-briefing28-Jan-2016/PGA-Briefing--Status-of-IAEG-SDGswork-on-global-SDG-indicators-28-Jan-2016.pdf

United Nations Statistics Division. (2016c). Work plans for Tier III indicators (as of 20 September 2016). New York, NY: United Nations Statistics Division. Retrieved from https://unstats.un.org/sdgs/files/meetings/ iaeg-sdgs-meeting-04/Tier\%20III\%20Work\%20Plans \%2020-9-16.pdf

United Nations Statistics Division. (2018a). Institutional information: Concepts and definitions. New York, NY: United Nations Statistics Division. Retrieved from https://unstats.un.org/sdgs/metadata/files/ Metadata-16-10-01.pdf

United Nations Statistics Division. (2018b). Tier classification for global SDG indicators. New York, NY: United Nations Statistics Division. Retrieved from https://unstats.un.org/sdgs/files/Tier\%20 Classification\%20of\%20SDG\%20Indicators_11\%20 May\%202018_web.pdf

Voces del Sur. (2019). Una región con claroscuros: Informe sombra sobre el cumplimiento del ODS 16.10.1 en 8 paises de LAC [A region split between light and shadows: Shadow report on the compliance of the SDG 16.10.1 in 8 LAC countries]. Retrieved from https://www.vocesdelsurunidas.org/wp-content/ uploads/2019/09/Informe-16.10.1-1.pdf

Worlds of Journalism. (n.d.). Homepage. Worlds of Journalism. Retrieved from www.worldsofjournalism.org

\section{About the Author}

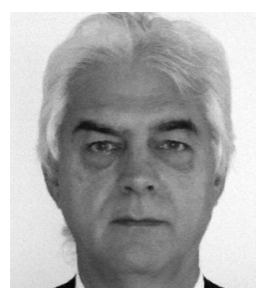

Guy Berger has led implementation of UNESCO's work on safety of journalists, media development, and freedom of expression since 2011. He previously headed the School of Journalism and Media Studies at Rhodes University, South Africa (1994-2010). 